Article

\title{
Innovative Use of Plastic for a Clean and Sustainable Environmental Management: Learning Cases from Ghana, Africa
}

\author{
Justice Kofi Debrah $^{1}$ (D), Diogo Guedes Vidal ${ }^{2}$ (D) and Maria Alzira Pimenta Dinis ${ }^{2, *(D)}$ \\ 1 Faculty of Science and Technology, University Fernando Pessoa (UFP), 4249-004 Porto, Portugal; \\ 40511@ufp.edu.pt \\ 2 UFP Energy, Environment and Health Research Unit (FP-ENAS), University Fernando Pessoa (UFP), \\ 4249-004 Porto, Portugal; diogovidal@ufp.edu.pt \\ * Correspondence: madinis@ufp.edu.pt
}

check for

updates

Citation: Debrah, J.K.; Vidal, D.G.; Dinis, M.A.P. Innovative Use of Plastic for a Clean and Sustainable Environmental Management: Learning Cases from Ghana, Africa. Urban Sci. 2021, 5, 12. https://doi. org/10.3390/urbansci5010012

Received: 6 January 2021

Accepted: 18 January 2021

Published: 22 January 202

Publisher's Note: MDPI stays neutral with regard to jurisdictional claims in published maps and institutional affiliations.

Copyright: (c) 2021 by the authors. Licensee MDPI, Basel, Switzerland. This article is an open access article distributed under the terms and conditions of the Creative Commons Attribution (CC BY) license (https:// creativecommons.org/licenses/by/ $4.0 /)$.

\begin{abstract}
Addressing the plastic problem requires rigorous attention and practical education for sustainability. Due to the common effective waste management practices in some parts of the world, the plastics' menace is generally well recognized and controlled worldwide. However, some developing countries do not have acceptable waste management practices, resulting in significant environmental, social, and health cross-cutting issues. Plastic is a significant threat to the environment in Ghana, specifically the urban environment and oceans. The new paradigm shift of virtually using non-biodegradable plastics in all daily products sold increases plastic waste in the environment, which creates problems, such as choked drainage system and breeding places for insects. The scale of these issues requires innovative and practical ideas to help solve this problem. The paper shows how plastic waste is innovatively and creatively converted to artifacts and pavement blocks in Ghana. These innovative ideas have contributed to reduce the volume of plastic waste and enhance environmental sustainability in Africa. The community's benefits involving friendly environmental activities are identified and represent learning cases from Ghana to the world, particularly to Africa.
\end{abstract}

Keywords: plastic waste management; innovation; environmental sustainability; learning cases (LC)

\section{Introduction}

Environmental sustainability has become an essential priority in the 21st century in most developing countries' ecological agendas. In recent years, maximum attention has been given to plastic pollution resulting in severe environmental problems caused by the lack of a waste management infrastructure, mass consumption of goods, and packaging of products globally [1]. In 2020, the global plastic contamination increased due to mismanagement of personal protective equipment for the COVID-19 pandemic, with a monthly estimate use of 129 billion face masks and 65 billion gloves [2-4].

Plastics are solid materials with one or more organic monomers forming polymers with a heavy molecular weight [5]. Plastics degrade at a slower rate due to their durability and the chemical bonds that resist the natural degradable process. Hence, plastic is classified according to its chemical structure, polarity (chemical process), and applications [6]. The chemical structure and temperature behavior of plastics (formation of heat application) allow them to be classified into thermoplastics and thermosets. Heated plastics that cannot be remolded are known to be thermosetting plastics. Oppositely, thermoplastics can be reheated, remolded, and cooled without causing any chemical changes. Examples of thermoplastics include plastic bags or polyethylene (PE), polyvinyl chloride (PVC), and nylon.

Plastic waste has become a challenging environmental issue globally, particularly in developing countries that have not invested in plastic recycling and collecting discarded 
plastics [7] and where the environmental issues are not still valued. According to Lebreton et al. [8] and Neilson's [9] studies, most plastics enter the oceans and lands and potentially damage the environment. In 2010, an estimated 4.8 to 12.7 million plastic waste enter globally into the sea worldwide [10]. Due to the cheap and easy production of plastics and the difficulty for plastics to break down through natural process [3,4], selective sorting of plastic waste has become a significant priority among government agencies, communities, non-governmental organizations (NGOs), and society due to the negative impact of the plastic contribution to the environment [10-15]. From 1950 to 2018, plastic waste production globally has increased to 6.3 billion metric tons, resulting in $12 \%$ incinerated, $9 \%$ recycled, and $79 \%$ untreated plastic $[11,16]$.

In 2016, worldwide nations produced 335 million metric tons of plastic [17]. The world plastic production went to 348 million tons in 2017 and 359 million metric tons in 2018, with China producing $29.4 \%$ of it compared with entire Europe $(18.5 \%)$ and that of Africa's (7.1\%) in 2017 [18,19]. Most of the plastics are made up of PE, polypropylene (PP), polystyrene (PS), and PVC, which can be used because of their chemical properties and density in different forms, such as bottles, sachets $[17,20]$, and thus commonly found in the rivers and marine environment [21,22]. Due to population increase and socioeconomic factors of current lifestyles, plastics are part of people's daily lives [23-25]. The rise in plastic waste disposal on roads, farms, water bodies results from people's perception, behavior, and attitude towards waste [26-28]. In countries where plastics are collected and recycled or incinerated, proper waste management or training is implemented [29,30]. Still, most developing countries lack municipal solid waste management facilities to manage the plastics. In those countries, plastics are or may be collected informally by different waste collectors moving from one point to another. Some studies support such a paradigm, i.e., a survey conducted in 2010 by Oteng-Ababio [31] and metropolitan waste management departments of Takoradi in Ghana indicated that $30 \%$ of 268 tons of waste generated in the Secondi-Takoradi metropolis is comprised of plastics [31,32]. The study further reported that Accra metropolis generated 2000 tons of waste, and Kumasi metropolis generated 1200 tons of waste, but only $60 \%$ and $65 \%$ of the corresponding wastes generated were collected in Accra Metropolitan Authority and Kumasi Metropolitan Authority [32]. In 2015 , a study by Miezah [33] also indicated that $14 \%$ of plastic waste is collected from the households in Ghana. Most plastics are disposed of at landfills, incinerated, and burnt by individuals at any open space within communities [31,32,34], which is not acceptable. These plastic disposal methods used in Ghana threaten the environment by polluting the atmospheric air with carbon monoxide (CO), nitrogen oxides (NOx), sulphur oxides (SOx), releasing dioxins, and other hazardous chemical pollutants, thus causing severe health problems [20,33-35] as well as releasing carbon dioxide $\left(\mathrm{CO}_{2}\right)$, which is known to be a significant contributor to the global warming [16]. Until more educational awareness and innovative recycling ideas are introduced in various communities for the sustainable plastic waste environment, plastic will continue to destroy Ghana's ecological environment, and the same will happen in most developing countries in Africa.

An important contribution to solve this issue, with particular emphasis on developing countries, is the Circular Economy (CE), which intends to shift the paradigm towards a more sustainable society in all dimensions: Social, economic and environmental. The main principle of $\mathrm{CE}$ is to add value to the products for a long period of time to minimize waste, namely, attributing a new function to a product that has lost the previous one $[29,35]$. According to the European Commission action plan [36], CE ensures a transition for the production of products more durable or easier to repair and to make transparent the production process to the consumers to allow them to make an informed decision. This means that $C E$ is restorative and regenerative because materials and products enter in a cycle, rather than being discarded. $\mathrm{CE}$ is explored in the contextualized learning examples in the Ghana context, presented in this article.

In Ghana's case, plastic waste generated varies from one municipality to another or one district to another. The exponential growth of population and migration of people to 
urban centers because of industrialization leads to high consumption of plastics. These plastics are indiscriminately discarded after use. A study conducted by Ampofo in 2013 [20] for the Center for Scientific and Industrial Research (CSRI) indicates that Ghana can release an average of GHC 1.2 million (EUR 206,896) monthly if the plastic waste generated is recycled systematically [20]. In 2016, Ghana imported over 10,000 metric tons of plastics, while the local companies in Accra manufactured or recycled an average of 38,927.57 metric tons of sorted plastics annually [37]. There has been an increase in plastics production companies and high annual importation of the plastics into Ghana due to the higher demand for packaging of products sold into the market and fewer recycling companies exist to add value to the used or unwanted plastics. According to Pwamang [38], Executive Director of the Environmental Protection Agency, about 2.58 million metric tons of raw plastics are imported into Ghana annually, and 73\% effectively ends up as waste [38]. It is estimated that about 270 tons of plastics are produced in Ghana [39], and 320 tons of plastic waste are also recycled in Ghana per day [40]. The remaining plastic waste is disposed of in the streets, oceans, and other parts of the environment, negatively affecting the environment and causing respiratory illnesses when burnt and floods when it rains.

Plastic waste can be managed and reduced through less plastic consumption, infrastructure provision for plastic waste management, and environmental awareness. Less plastic consumption prevents unnecessary plastic packaging if choosing eco-friendlier or degradable material for packaging. Through formal and informal education and increasing awareness, long-term positive plastic environmental behavior change can be created, leading to reduced waste disposal through moral responsibility [41-44]. Education and awareness must aim to enforce reducing plastic consumption, reducing waste disposal, and improving behavioral change, thus minimizing plastic waste's negative environmental consequences.

Part of the plastic waste problems include releasing harmful chemicals from chlorinated plastics into the soil, which end up in the plants and water, and choking drains can be solved through innovative ideas. According to Lee et al. [45], innovative ideas are the primary key to managing plastics and creating an excellent sustainable business environment, in the entire world. These innovative ideas, which aim to serve as environmental goals, can boost managing plastic waste and improve environmental sustainability in developing countries. Sustainable innovation can be classified into weak and strong sustainability [46-48], depending on the environmental impact level [49]. The environmental impact level improves and minimizes ecological damage and promotes business [45]. For sustainable management practice, plastics waste must be in good condition and equally fit for innovative business models or ideas [50]. In plastic waste innovation, the innovators add value to plastic waste generated to recover the plastics and reduce plastic waste disposal.

To help solve the problems associated with plastics globally, many private companies have now responded well to minimize excessive plastics disposed to the environment through business and innovative minds [51] in Africa. This study aims to present learning cases (LC) in Ghana, Africa, seeking to convert plastic into other useful products pursuing environmental sustainability within the communities where the Trashy Bags and Nelplast Ghana Limited companies are located.

\section{The Importance of Learning Cases Approach}

The LC approach is a problem-solving process that involves participatory discussion through a critical thinking mind or skills and learning process [52]. This approach is recognized as extremely useful to reflect on problems and to innovate through learning [53]. LC methodology helps individuals generate innovative ideas that allow others to learn for knowledge impartation [54]. Alongside, LC help to improve the implementation of the UN 2030 Agenda [55] at a local level and to involve local communities and stakeholders in the transformative process towards a better society [56,57]. The LC approach is essential in knowledge transfer. It improves analyzing skills to use one's senses and the doctrine of 
decision-making to solve problems. LC approach helps in implementing innovative ideas and knowledge for critical thinking skills.

The two LC described below will demonstrate how to best use plastic material and, at the same time, disseminate such ideas creatively and sustainably. They will act as a platform to share their stories and knowledge.

\section{Trashy Bags Learning Case Presentation}

Trashy Bags [39] is a Ghana company that converts used plastics to handbags, dresses, pencil cases, caps, among others. Trashy Bags Company has 60 workers who use plastic sachets collected from the local environment for innovative products. About 180,000 plastic sachets (i.e., $275.143 \mathrm{~kg}$ or $6000 \mathrm{bags}$ ) on the streets are reused per month.

\subsection{Pre-Process for Production in Trashy Bags}

In the innovative idea built up by Trashy Bags, the collected plastic sachets are sorted within the environment and then cut open. They are manually washed thoroughly, dried in the sun, and straightened for production (Figure 1).

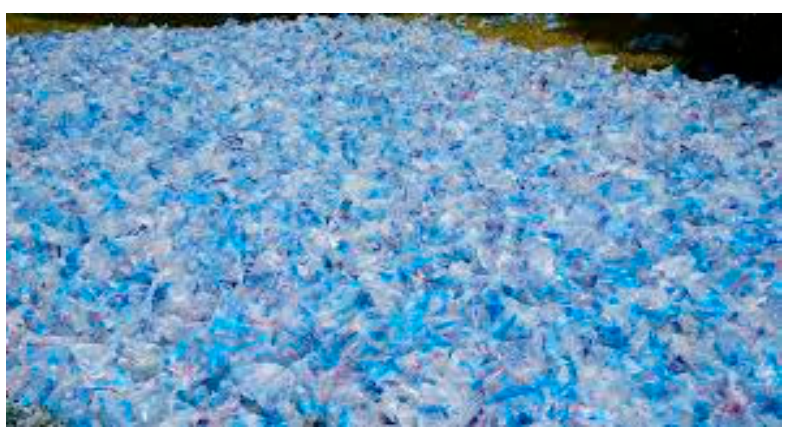

Figure 1. Collected cut water sachets, manually washed and dried. Source: Trashy Bags [39].

\subsection{Trashy Bags Production Process}

The opened, washed, and dried plastic sachets are sewn into sheets. The sheets are made in particular sizes depending on the final product. The sheets are then converted into over 30 bags and other different designed products. These designed products, which come with specifications and other accessories, contribute to minimizing the environmental problem caused by plastics in Ghana (Figure 2).

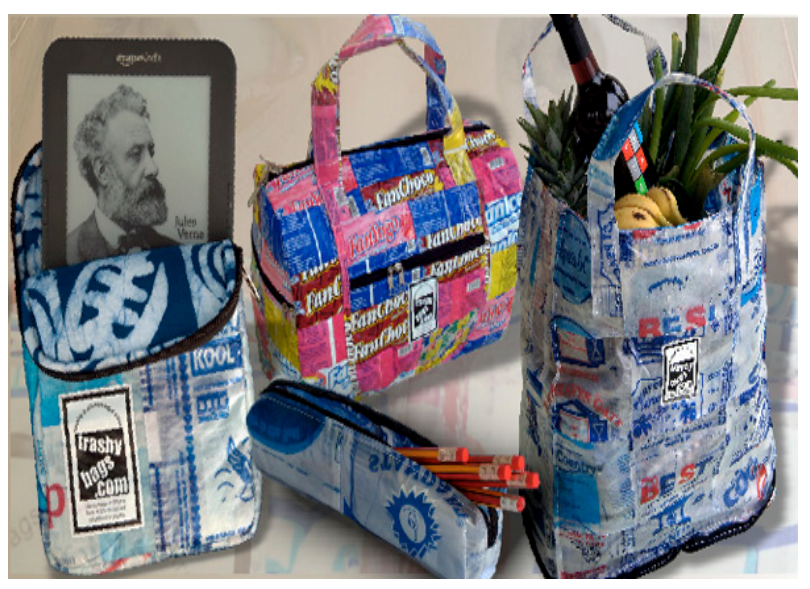

Figure 2. Bags created from plastics collected from the environment. Source: Trashy Bags [39].

\subsection{Trashy Bags Innovation Benefits}

The innovative plastic waste idea from Trashy Bags has helped reduce the plastics that contaminate the streets and flood in the Ablekuman community in Accra, Ghana, 
Africa, by about $257.143 \mathrm{~kg}$ (6000 packs) per month, aiming to contribute to environmental sustainability. Plastic waste decreases when more orders are placed on Trashy Bags, such as school bags, hats, car mats, etc. The process of high demand for Trashy Bags products leads to purchasing more plastic waste from other surrounding communities in Accra, Ghana. In the Trashy Bags process, the plastics within the company's localities are collected, making the environment clean, free from plastic, and healthy. Trashy Bags uses its environmental sustainability program to sensitize the community and people about the environmental damage associated with indiscriminate plastic waste disposal. This is done by using company volunteers to undertake community engagement programs to sensitize people about environmental problems with plastic waste and how to keep the environment clean. The outreach education, collectors of sachets, sewers, or stitches of the sachets into bags also create employment for the people within the localities, resulting in important economic benefits, crucial in developing countries in Africa.

\section{Nelplast Ghana Limited Learning Case Presentation}

Nelplast Ghana Limited [58] company in Ghana has 74 direct employers and about 230 indirect workers. The company uses its creative ideas to convert plastic waste into pavement blocks. In the production of pavement blocks using plastic waste, only PVC plastics are excluded. About 19,200 kg of plastic waste is required for monthly production.

\subsection{Pavement Blocks Production Process}

The collected plastic waste from the environment is shredded down to fine threads by locally fabricated equipment. The plastic pavement blocks are made when $70 \%$ of the shredded plastic waste is mixed with $30 \%$ of ordinary sand. The plastic pavement blocks are more robust and resilient than cement blocks due to the plastic origins' binding agent of physical elasticity.

A study conducted by Tulashie et al. [59] indicates that plastic pavement blocks' strength depends on sand mixture types. The study further showed that the plastic-pit sand pavement block (PPPB) had a fibrous surface, smaller pore volume, and grain size than the plastic-sea sand pavement block (PSPB). The same study further explains that a high quantity of plastics lower water absorptivity of plastic blocks and enhance compressive force, thus in the production of pavement blocks using plastic waste, PVC plastics are excluded (Figure 3).

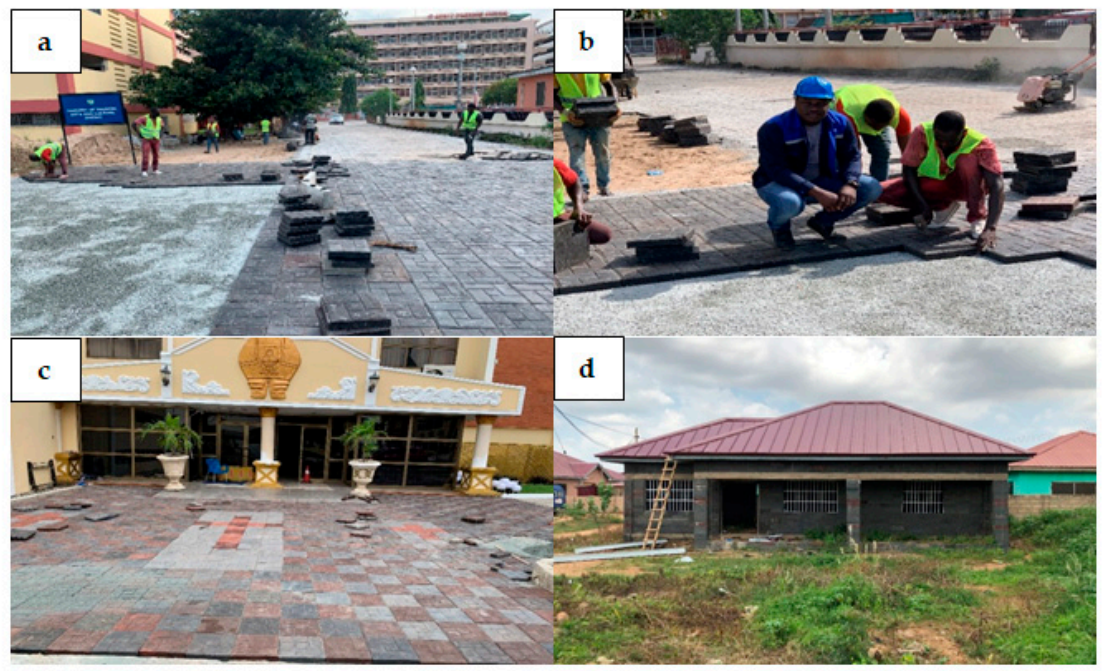

Figure 3. Shredded plastic waste mixed with sand to form pavement blocks. (a) Arranging plastic pavement blocks to lay, (b) plastic pavement blocks being laid, (c) completed laid plastic pavement block, (d) house constructed from plastics. Source: Nelplast Ghana Limited [58]. 


\subsection{Economic Benefits of Plastic Waste Pavement Block}

Nelplast Ghana Limited uses about 19,200 kg of plastic waste to produce about 4800 pieces of pavement blocks per month. Thus, 200 plastic blocks are constructed from 800 $\mathrm{kg}$ of plastic waste in a day. Nelplast Ghana Limited's innovative idea reduces plastic waste in Ghana, thus contributing to the minimization of plastic environmental problems and public health issues. The plastic pavement blocks obtained from the plastic waste and the sand mixture are of remarkable resilience for paving roads, hospital parks, towns, and villages at cheaper costs than those acquired with traditional asphalt. A study conducted by [60] indicates that plastic pavement blocks could support a load of $53 \%$ higher than concrete pavers before they rupture, with a maximum load of $36.77 \mathrm{kN}$, whereas hydraulic concrete pavers have a full load of $19.64 \mathrm{kN}$. The study further indicated the compression test of hydraulic concrete pavements load is $340 \mathrm{kN}$, while plastic waste pavement block load $460 \mathrm{kN}$ [60]. Concerning pavement blocks' durability, plastic paver blocks may perform better in flood-prone areas and saline content due to their lower water absorption power [61]. The entire production chain of Nelplast Ghana Limited creates jobs for the people within the community and contributes to plastic environmental sustainability.

A summary of the environmental, economic, and social benefits of these two LC and correspondent contributions to the UN 2030 Agenda are presented in Table 1.

Table 1. Environmental, economic, and social benefits of the two LC presented and correspondent contributions to the UN 2030 Agenda.

\begin{tabular}{|c|c|c|c|}
\hline Benefits & Trashy Bags & Nelplast Ghana Limited & $\begin{array}{l}\text { UN } 2030 \\
\text { Agenda }\end{array}$ \\
\hline Environmental & $\begin{array}{l}180,000 \text { plastic sachets } \\
\text { on the streets are } \\
\text { collected per month. } \\
\text { Reduce the plastics that } \\
\text { contaminate the streets } \\
\text { and cause floods. }\end{array}$ & $\begin{array}{c}19,200 \mathrm{~kg} \text { of plastic waste is } \\
\text { collected to produce about } \\
4800 \text { pieces of pavement blocks } \\
\text { per month. }\end{array}$ & $\begin{array}{c}\text { SDG } 3,6,11,13, \\
14 \text { and } 15\end{array}$ \\
\hline Economic & $\begin{array}{l}\text { Create employment for } \\
\text { the people within the } \\
\text { localities. } \\
\text { Contribute to the local } \\
\text { economy. }\end{array}$ & $\begin{array}{l}\text { Create employment for the } \\
\text { people within the localities. } \\
\text { Plastic paver blocks perform } \\
\text { better in flood-prone areas and } \\
\text { saline content due to their } \\
\text { lower water absorption power }\end{array}$ & $\begin{array}{l}\text { SDG } 1,2,8,9,10 \\
\text { and } 11\end{array}$ \\
\hline Social & $\begin{array}{c}\text { Sensitize the } \\
\text { community and people } \\
\text { about the } \\
\text { environmental damage } \\
\text { associated with } \\
\text { indiscriminate plastic } \\
\text { waste disposal. } \\
\text { Promote social } \\
\text { cohesion and } \\
\text { empowerment. }\end{array}$ & $\begin{array}{l}\text { Enhance local communities' } \\
\text { sustainability awareness. }\end{array}$ & $\begin{array}{c}\text { SDG } 11,12 \text { and } \\
17\end{array}$ \\
\hline \multicolumn{4}{|c|}{ Contribution to the local circular economy } \\
\hline
\end{tabular}

\section{Discussion}

There is an enormous threat caused by plastics to the environment within Ghana and African communities in general. It is known that plastics that are scattered and found on drainages and nearby surroundings serve as a source of breeding stocks of mosquitoes and other insects [62], a critical source of health concern in African countries due to existing high temperatures. Rampant disposal of plastics in trenches could choke and block free floor water during the rainy season and originate flooding [63]. Plastics can also suffocate ruminant animals when they graze or eat the grass that contains plastics [64]. The plastic 
that is eaten prevents the ruminant animals from regurgitating their food, choking them to death in most cases.

Due to the non-degradable or slower nature of plastic degrading, plastics disposal has become a major complication within African countries' environmental sustainably. This makes the management of plastic quite difficult. Plastic waste is often burnt in the open air in some African countries where environmental awareness is not present. This process emits many toxic gases into the atmosphere, thereby polluting the air, destroying the ozone layer, and compromising its protective properties $[65,66]$, with important negative consequences to global warming and climate change topics. Some of these gaseous substances include $\mathrm{NO}_{\mathrm{x}}, \mathrm{CO}$, methane $\left(\mathrm{CH}_{4}\right)$, and $\mathrm{SO}_{\mathrm{x}}$. The process increases the risk of health hazards, including cancer $[67,68]$. The essence of the innovative business ideas, such as the Trashy Bags and Nelplast Ghana Limited, contributes to minimizing and solving some of the problems associated with plastic waste in Ghana, a developing country in Africa.

The two innovative business LC models, presented within the scope of plastic waste sustainability, offer jobs and improve people's livelihood, also enhancing the community's local economies, as suggested by the literature [69,70], namely in developing countries [71], as in the case of Ghana in Africa. These innovative business models reduce the total plastic waste generated and scattered in entire surroundings of greater Accra region communities to more than $19,457.143 \mathrm{~kg}(54.35 \%)$ in a month, contributing to the implementation of 13 of the 17 SDGs at a local level. The two LC activities use creative ideas to reduce some of the people's dependency condition in the Trashy Bags and Nelplast Ghana Limited local communities by permanently employing over 134 regular factory workers, contributing to local economic sustainability, so important in Ghana and in most African developing countries. This excludes security personnel and food vendors working in the companies' premises and over 500 plastic waste collectors paid per $1 \mathrm{~kg}$ of the collected plastic.

The 2020 market survey in Ghana indicates that more than GHC 6.7 million (EUR 1.15 million) are paid to the plastic waste collectors per month [40], including the LC collectors. The two LC operations have reduced the companies' pollutant emissions since most plastic waste collected is sent for recycling but not incinerated and thus avoid emitting hazardous chemical compounds to the atmosphere. There is a reduction of plastic waste to the landfills in the LC communities because plastics sorted by various households are sent to the companies for sale. Continued education by volunteers and the price tag attached to collect plastic waste has encouraged more people to sort plastics. Education creates environmental awareness, understanding, and improving of environmental behavior [72]. These innovative ideas have reduced the imports of resources such as cement and plastic artifact gifts, generally contributing to Ghana's local environmental sustainability.

The products obtained from the innovative ideas presented in this text are now serving as an alternative for other similar materials in the Ghana market at an affordable price, including carrier bags, refuse bags, buckets, dustbins, shoe soles, doormats, and car mats, and pavement blocks. Lastly, these LC innovative ideas present a clear example of CE. Both apply a holistic approach to the problem of plastic pollution by being aware of how their products impact the wider system of collection and recycling in Ghana. Moreover, they promote collaborative partnerships to innovate, contributing to the local economy and community empowerment in a developing country in Africa.

\section{Conclusions}

The innovative business model for sustainable plastic waste management represented by the two companies presented in this text, Trashy Bags and Nelplast Ghana Limited in Ghana, Africa, will help minimize the plastic material discarded to the environment, depicting a severe threat to Ghana's ecological environment. Trashy Bags and Nelplast Ghana Limited companies reduced the total plastic waste in the greater Accra region communities, Ghana, by over $257.143 \mathrm{~kg}(0.7 \%)$ and $19,200 \mathrm{~kg}(62.34 \%)$ of plastics a month. The plastics that end up on streets, oceans, and causing flooding are collected by some people, serving as an essential employment and income source in Ghana. 
Trashy Bags and Nelplast Ghana Limited companies have contributed to the Ghana's local communities' development by promoting health and safety awareness and plastic waste recycling management practices. They also reduce the damage caused to animals, humans, and plants through plastic waste toxic pollutants.

This innovative way for sustainable plastic management practices in Ghana, Africa, must be further supported by the government and prioritized to achieve sustainable development in communities. It will serve as capacity building for individuals and strengthen the reliable waste management infrastructures at Ghana district levels in the future. There should be a clear policy in using and promoting products obtained through innovative ideas within environmental sustainability, valued and supported by citizens and the local management structure. Citizens and students, in particular, may use the plastics from Trashy Bags in school. At the same time, contractors could construct school buildings and walkways with the plastic and pavement blocks by Nelplast Ghana Limited.

Regarding the importance of adopted strategies for the implementation of CE, local governments must be aware of the significant role that they can play in the transition towards sustainable and circular societies. This local power can request reuse and recycling, to design local plans and set up environmental requirements to integrate the CE model within the city sustainable development. Beyond the benefits to the local communities and economic and environmental dimensions, the actions developed by local power can result in a greater attractiveness of the area by being recognized as a source of innovation, reshaping local organization and governance in the context of Africa's developing countries.

Author Contributions: Conceptualization, J.K.D.; data curation, J.K.D.; formal analysis, J.K.D. and D.G.V.; investigation, J.K.D.; methodology, J.K.D.; supervision, M.A.P.D.; validation, D.G.V. and M.A.P.D.; visualization, J.K.D., D.G.V. and M.A.P.D.; writing-original draft, J.K.D.; writing-review \& editing, J.K.D., D.G.V. and M.A.P.D. All authors have read and agreed to the published version of the manuscript.

Funding: This research received no external funding.

Institutional Review Board Statement: Not applicable.

Informed Consent Statement: Not applicable.

Data Availability Statement: No new data were created or analyzed in this study. Data sharing is not applicable to this article.

Acknowledgments: The authors wish to acknowledge the Trashy Bag and Nelplast Ghana Limited for assistance and shared knowledge within innovative business models on sustainable plastic waste management practices in Ghana.

Conflicts of Interest: The authors declare no conflict of interest.

\section{References}

1. Gutberlet, J. Waste in the city: Challenges and opportunities for urban agglomerations. In Urban Agglomeration; Ergen, M., Ed.; IntechOpen: London, UK, 2017; pp. 191-208.

2. Prata, J.C.; Silva, A.L.P.; Walker, T.R.; Duarte, A.C.; Rocha-Santos, T. COVID-19 pandemic repercussions on the use and management of plastics. Environ. Sci. Technol. 2020, 54, 7760-7765. [CrossRef]

3. Patrício Silva, A.L.; Prata, J.C.; Walker, T.R.; Campos, D.; Duarte, A.C.; Soares, A.M.V.M.; Barcelò, D.; Rocha-Santos, T. Rethinking and optimising plastic waste management under COVID-19 pandemic: Policy solutions based on redesign and reduction of single-use plastics and personal protective equipment. Sci. Total Environ. 2020, 742, 140565. [CrossRef] [PubMed]

4. Silva, A.L.P.; Prata, J.C.; Walker, T.R.; Duarte, A.C.; Ouyang, W.; Barcelò, D.; Rocha-Santos, T. Increased plastic pollution due to COVID-19 pandemic: Challenges and recommendations. Chem. Eng. J. 2021, 405, 126683. [CrossRef] [PubMed]

5. PlasticsEurope. What Are Plastics? Available online: https://www.plasticseurope.org/en/about-plastics/what-are-plastics (accessed on 7 December 2020).

6. Institute of Plastic Technology Classification and Identification of Plastics. Available online: www.aimplas.net/blog/plasticsidentification-and-classification/ (accessed on 7 December 2020). 
7. Kumi-Larbi, A.; Yunana, D.; Kamsouloum, P.; Webster, M.; Wilson, D.C.; Cheeseman, C. Recycling waste plastics in developing countries: Use of low-density polyethylene water sachets to form plastic bonded sand blocks. Waste Manag. 2018, 80, 112-118. [CrossRef] [PubMed]

8. Lebreton, L.; Slat, B.; Ferrari, F.; Sainte-Rose, B.; Aitken, J.; Marthouse, R.; Hajbane, S.; Cunsolo, S.; Schwarz, A.; Levivier, A.; et al. Evidence that the Great Pacific Garbage Patch is rapidly accumulating plastic. Sci. Rep. 2018, 8, 4666. [CrossRef]

9. Neilson, A. Considering the importance of metaphors for marine conservation. Mar. Policy 2018, 97, 239-243. [CrossRef]

10. Jambeck, J.R.; Geyer, R.; Wilcox, C.; Siegler, T.R.; Perryman, M.; Andrady, A.; Narayan, R.; Law, K.L. Plastic waste inputs from land into the ocean. Science 2015, 347, 768-771. [CrossRef]

11. Geyer, R.; Jambeck, J.R.; Law, K.L. Production, use, and fate of all plastics ever made. Sci. Adv. 2017, 3. [CrossRef]

12. Indraratna, B.; Qi, Y.; Tawk, M.; Heitor, A.; Rujikiatkamjorn, C.; Navaratnarajah, S.K. Advances in ground improvement using waste materials for transportation infrastructure. Proc. Inst. Civ. Eng.-Ground Improv. 2020. [CrossRef]

13. Yujie, Q.; Buddhima, I.; Richard, C.M. Predicted behavior of saturated granular waste blended with rubber crumbs. Int. J. Geomech. 2019, 19, 4019079. [CrossRef]

14. Green, A.; Bisarnsin, T.; Love, E.A. Pultruded reinforced plastics for civil engineering structural applications. J. Reinf. Plast. Compost. 1994, 13, 942-951. [CrossRef]

15. Yujie, Q.; Buddhima, I. Energy-based approach to assess the performance of a granular matrix consisting of recycled rubber, steel-furnace slag, and coal wash. J. Mater. Civ. Eng. 2020, 32, 4020169. [CrossRef]

16. Laura, P. A Whopping 91\% of Plastic Isn't Recycled. Available online: https:/ /www.nationalgeographic.org/article/whopping91-percent-plastic-isnt-recycled/ (accessed on 10 December 2020).

17. PlasticsEurope. Plastics—The Facts 2017; PlasticsEurope Deutschland e. V. and Messe Düsseldorf: Brussels, Belgium, 2017.

18. PlasticsEurope. Plastics—The Facts 2018; PlasticsEurope Deutschland e. V. and Messe Düsseldorf: Brussels, Belgium, 2018.

19. PlasticsEurope. Plastics-The Facts 2019; PlasticsEurope Deutschland e. V. and Messe Düsseldorf: Brussels, Belgium, 2019.

20. Ampofo, S.K. Report on the Option for the Effective Management of Plastic Waste in Ghana; Friends of the Nation: Takoradi, Ghana, 2013.

21. Andrady, A.L. Microplastics in the marine environment. Mar. Pollut. Bull. 2011, 62, 1596-1605. [CrossRef] [PubMed]

22. Prata, J.C. Plastic litter in our oceans: A case for government action. Ocean Yearb. Online 2018, 32, 283-313. [CrossRef]

23. Yoada, R.M.; Chirawurah, D.; Adongo, P.B. Domestic waste disposal practice and perceptions of private sector waste management in urban Accra. BMC Public Health 2014, 14, 697. [CrossRef]

24. Oliveira, G.M.; Vidal, D.G.; Ferraz, M.P. Urban lifestyles and consumption patterns. In Sustainable Cities and Communities. Encyclopedia of the UN Sustainable Development Goals; Filho, W.L., Azul, A.M., Brandli, L., Özuyar, P.G., Wall, T., Eds.; Springer Nature Switzerland AG: Cham, Switzerland, 2020; pp. 851-860. ISBN 978-3-319-71061-7.

25. Dutta, S.; Nadaf, M.B.; Mandal, J.N. An overview on the use of waste plastic bottles and fly ash in civil engineering applications. Procedia Environ. Sci. 2016, 35, 681-691. [CrossRef]

26. Afroz, R.; Hanaki, K.; Tuddin, R.; Ayup, K. A survey of recycling behaviour in households in Dhaka, Bangladesh. Waste Manag. Res. 2010, 28, 552-560. [CrossRef]

27. Sarbassov, Y.; Sagalova, T.; Tursunov, O.; Venetis, C.; Xenarios, S.; Inglezakis, V. Survey on household solid waste sorting at source in developing economies: A case study of Nur-Sultan City in Kazakhstan. Sustainability 2019, 11, 6496. [CrossRef]

28. Padilla, A.J.; Trujillo, J.C. Waste disposal and households' heterogeneity. Identifying factors shaping attitudes towards sourceseparated recycling in Bogotá, Colombia. Waste Manag. 2018, 74, 16-33. [CrossRef]

29. Van Eygen, E.; Laner, D.; Fellner, J. Circular economy of plastic packaging: Current practice and perspectives in Austria. Waste Manag. 2018, 72, 55-64. [CrossRef]

30. Alemu, C.; Dhanai, A. Geotechnical engineering applications of waste plastic bottle. Int. Res. J. Eng. Technol. 2018, 5, 37-40.

31. Oteng-Ababio, M. Private sector involvement in solid waste management in Ghana: The case of the Greater Accra Metropolitan Area (GAMA). Waste Manag. Res. 2010, 28, 322-329. [CrossRef] [PubMed]

32. Fei-Baffoe, B.; Nyankson, E.; Gorkeh-Miah, J. Municipal Solid Waste Management in Sekondi-Takoradi Metropolis, Ghana. J. Waste Manag. 2014, 1-9. [CrossRef]

33. Miezah, K.; Obiri-Danso, K.; Kádár, Z.; Fei-Baffoe, B.; Mensah, M.Y. Municipal solid waste characterization and quantification as a measure towards effective waste management in Ghana. Waste Manag. 2015, 46, 15-27. [CrossRef]

34. Hopewell, J.; Dvorak, R.; Kosior, E. Plastics recycling: Challenges and opportunities. Philos. Trans. R. Soc. Lond. B Biol. Sci. 2009, 364, 2115-2126. [CrossRef]

35. Robaina, M.; Murillo, K.; Rocha, E.; Villar, J. Circular economy in plastic waste-Efficiency analysis of European countries. Sci. Total Environ. 2020, 730, 139038. [CrossRef]

36. European Commission. Closing the Loop - An EU Action Plan for the Circular Economy; European Commission: Brussels, Belgium, 2015.

37. Kortei, N.K.; Quansah, L. Plastic Waste Management in Ghana-A Complete Failure and the Consequences. 2016. Available online: https:/ / www.graphic.com.gh/features/opinion/plastic-waste-management-in-ghana-a-complete-failure-and-theconsequences.html (accessed on 12 December 2020).

38. Aimplas. Classification and Identification of Plastics. 2019. Available online: https://www.aimplas.net/blog/plasticsidentification-and-classification/ (accessed on 27 December 2020). 
39. Trashy Bags Project Trashy Bags. Available online: http://trashybags.org/ (accessed on 7 December 2020).

40. Bert, K. Market Survey Waste and Circular Economy in Ghana; Holland Circular Hotspot: Hoofddorp, The Netherlands, 2019.

41. Hartley, B.L.; Pahl, S.; Holland, M.; Alampei, I.; Veiga, J.M.; Thompson, R.C. Turning the tide on trash: Empowering European educators and school students to tackle marine litter. Mar. Policy 2018, 96, 227-234. [CrossRef]

42. Licy, C.D.; Vivek, R.; Saritha, K.; Anies, T.K.; Josphina, C.T. Awareness, attitude and practice of school students towards household waste management. J. Environ. 2013, 2, 147-150.

43. Ifegbesan, A. Waste management awareness, knowledge, and practices of secondary school teachers in Ogun State, Nigeriaimplications for teacher education. J. Solid Waste Technol. Manag. 2011, 37, 221-234. [CrossRef]

44. Maddox, P.; Doran, C.; Williams, I.D.; Kus, M. The role of intergenerational influence in waste education programmes: The THAW project. Waste Manag. 2011, 31, 2590-2600. [CrossRef]

45. Lee, S.; Jeong, M.; Authors, F.; Bydlowski, S.; Carton, S.; Valle, F.; Cohen, P.R.; Levesque, H.J.; Contractor, F.; Hsu, C.; et al. Experiential and Informational Knowledge, Architectural Marketing; Prentice-Hall Inc.: Upper Saddle River, NJ, USA, 2005; Volume 40, pp. 49-58. [CrossRef]

46. Pelenc, J.; Ballet, J.; Dedeurwaerdere, T. Weak Sustainability Versus Strong Sustainability. Brief for GSD. 2015. Available online: https:/ / sustainabledevelopment.un.org/content/documents / 6569122-Pelenc-Weak\%20Sustainability\%20versus\%20 Strong\%20Sustainability.pdf (accessed on 8 December 2020).

47. Dietz, S.; Neumayer, E. Weak and strong sustainability in the SEEA: Concepts and measurement. Ecol. Econ. 2007, 61, 617-626. [CrossRef]

48. Dias, R.C.; Seixas, P.C.; Lobner, N. Sustainable development and ecological modernization: Boundary discourses between "strong" and "weak" approaches. J. Sustain. Dev. 2020, 4, 268-278. [CrossRef]

49. Landon-Lane, M. Corporate social responsibility in marine plastic debris governance. Mar. Pollut. Bull. 2018, 127, 310-319. [CrossRef] [PubMed]

50. Dijkstra, A.; Beukering, P.; Brouwer, R. Business models and sustainable plastic management: A systematic review of the literature. J. Clean. Prod.. 2020, 258, 120967. [CrossRef]

51. Vince, J.; Hardesty, B. Plastic pollution challenges in marine and coastalenvironments: From local to global governance. Restor Ecol. 2017, 25, 123-128. [CrossRef]

52. Lundgren, M. Undervisning på hög nivå: Fallstudiemetodikens möjligheter och begränsningar i undervisning inom företagsekonomi. Högre Utbild. 2013, 3, 211-224.

53. Dotti, N.F. Knowledge, Policymaking and Learning for European Cities and Regions. From Research to Practice; Edward Elgar Publishing: Cheltenham, UK, 2018; ISBN 978-1-78643-363-3.

54. Krusenvik, L. Using Case Studies as a Scientific Method: Advantages and Disadvantages; Linnéa Krusenvik Halmstad University: Halmstad, Sweden, 2016.

55. United Nations. Transforming Our World: The 2030 Agenda for Sustainable Development. Resolution Adopted by the General Assembly on 25 September 2015, A/RES/70/1; United Nations: Geneva, Switzerland, 2015.

56. Williams, L.; Tahtinen, L.; Costa, N.; Karst, L.; Proden, E. Stakeholder Engagement \& the 2030 Agenda: A Pratical Guide; United Nations: New York, NY, USA, 2020.

57. da Silva, C.G.; Dias, R.C.; Seixas, P.C.; Baptista, L.M. Oeiras smart: Um learning case de inteligência territorial [Oeiras smart: A learning case of territorial intelligence]. Desenvolv. Reg. Debate 2020, 10, 90-112. [CrossRef]

58. Nelplast Ghana Ltd Nelplast Ghana Limited. Available online: https://www.nelplastgh.com/ (accessed on 7 December 2020).

59. Tulashie, S.K.; Boadu, E.K.; Kotaka, F.; Mensah, D. Plastic wastes to pavement blocks: A significant alternative way toreducing plastic wastes generation and accumulation in Ghana. Constr. Build. Mater. 2020, 241, 118044. [CrossRef]

60. Chaves-Pabón, S.B.; Osorio-Baquero, E.; Molano-Barrera, C.W.; Ospina-García, M.A.; Lizarazo-Godoy, J.O. Technical and Economic Comparison between Recycled Plastic and Hydraulic Concrete Pavers. 2020. Available online: https://www. revistaespacios.com/a20v41n21/a20v41n21p24.pdf (accessed on 7 December 2020).

61. TA, T. The use of plastic waste as transition materials in the production of pavement blocks. Civ. Eng. Res. J. 2019, 9, 8-13. [CrossRef]

62. Krystosik, A.; Njoroge, G.; Odhiambo, L.; Forsyth, J.E.; Mutuku, F.; LaBeaud, A.D. Solid wastes provide breeding sites, burrows, and food for biological disease vectors, and urban zoonotic reservoirs: A call to action for solutions-based research. Front. Public Health 2020, 7, 405. [CrossRef]

63. de Morais Vieira, V.H.A.; Matheus, D.R. The impact of socioeconomic factors on municipal solid waste generation in São Paulo, Brazil. Waste Manag. Res. 2017, 36, 79-85. [CrossRef]

64. Jâms, I.B.; Windsor, F.M.; Poudevigne-Durance, T.; Ormerod, S.J.; Durance, I. Estimating the size distribution of plastics ingested by animals. Nat. Commun. 2020, 11, 1594. [CrossRef] [PubMed]

65. Verma, R.; Vinoda, K.S.; Papireddy, M.; Gowda, A.N.S. Toxic pollutants from plastic waste-A review. Procedia Environ. Sci. 2016, 35, 701-708. [CrossRef]

66. Simoneit, B.R.T.; Medeiros, P.M.; Didyk, B.M. Combustion products of plastics as indicators for refuse burning in the atmosphere. Environ. Sci. Technol. 2005, 39, 6961-6970. [CrossRef] 
67. Maia, R.L.; Vidal, D.G.; Oliveira, G.M. Ambiente e Saúde: Uma leitura comparada a partir das estatísticas dos meios rurais e urbanos [Environment and Health: A comparative reading from rural and urban statistics]. Obra Nasce Rev. Arquit. Univ. Fernando Pessoa 2018, 13, 57-69.

68. Barreira, E.; Pontes, M.; Maia, R.L.; Oliveira, G.M.; Vidal, D.G. Cancro do Pulmão e Poluição: Um estudo transversal [Lung Cancer and Pollution: A cross-sectional study]. Onco. News 2018. [CrossRef]

69. Weinberg, A.S.; Pellow, D.N.; Schnaiberg, A. Urban Recycling and the Search for Sustainable Community Development; Princeton University Press: Princeton, NJ, USA, 2000; ISBN 9780691050140.

70. Gutberlet, J. Urban Recycling Cooperatives: Building Resilient Communities; Routledge: London, UK, 2016.

71. Wilson, D.C.; Velis, C.; Cheeseman, C. Role of informal sector recycling in waste management in developing countries. Habitat Int. 2006, 30, 797-808. [CrossRef]

72. Hartley, B.L.; Richard, C.; Thompson, S.P. Marine litter education boosts children's understanding and self-reported actions. Mar. Pollut. Bull. 2015, 90, 209-217. [CrossRef] 